Wildenthal, Lora. Review of How to Accept German Reparations, by Susan Slyomovics. German History 33, no. 2 (2015): 341-343. doi: 10.1093/gerhis/ghv009.

\title{
How to Accept German Reparations
}

\author{
How to Accept German Reparations . By Susan Slyomovics. Philadelphia: \\ University of Pennsylvania Press. 2014. x +373 pp. $£ 45.50$.
}

Lora Wildenthal, Rice University

Susan Slyomovics, an anthropologist of North Africa and the Middle East, has woven together histories - from her family, post-Holocaust Germany, post-colonial France and North Africa and Israel — with theoretical approaches to money, reparations and mourning to create this idiosyncratic, far-ranging, well written book. Each of the seven chapters circles around its subject, so that each chapter is never about just one thing. Five chapters concern Slyomovics's family and intertwined analyses drawing especially on Georg Simmel and Marcel Mauss; two chapters turn to North African and Israeli/Palestinian material to make important arguments about reparations and colonialism.

The author's mother and grandmother together survived Mátészalka ghetto, Auschwitz and the slave labour camps Plaszow, near Cracow, and Markkleeberg, near Leipzig. The mother and daughter were compelled to pretend to be sisters - otherwise, camp guards would have guessed the mother's true age, which was just over the maximum for a slave labourer. The book's point of departure is the divergence between these powerfully bonded women over how to respond to the opportunity to apply for German reparations. The author's grandmother, Gizella Elefant Holländer, immediately applied in the wake of the 1952 West German law on reparations to Jewish victims of Nazism. Indeed, one could say that she had begun applying at the moment of her liberation, when she had the presence of mind to obtain an affidavit from her erstwhile overseer, and one could say that she never stopped applying, as she applied for new forms of reparations as they emerged: for psychological harm from West Germany in 1965 and for the death of her brother-in-law from Hungary in the 1990s, the latter process remaining incomplete at the time of her death. The author's mother, Vera Slyomovics, refused to seek reparations during all those years. Then in 1999, the year of her mother's death, she changed her mind, apparently choosing to replace her mother as the 'designated family representative and recipient of German blood money’ (p. 51). The barest facts about the application process, including the very modest amounts disbursed, suggest what a strange experience that must have been: her application was rejected in 1999; she applied in 2000, when she received a lump sum of $\$ 5,000$; she was sent an unsolicited lump sum of \$1,000 in 2002; she applied in 2002, and was awarded a 
lifetime monthly pension of ca. $\$ 370$; she applied in a later year, receiving a lump sum of $\$ 5,000$; and applied in 2007 with an unspecified outcome (pp. 3, 6-7, 32).

Slyomovics spins multiple, complex narratives out of her investigation of her grandmother's and mother's decisions. To list some of them here is less elegant than their presentation in the book, but serves a practical purpose in this brief review. What actually happened to these women and other family members and friends, during those years? Despite Slyomovics's lifelong absorption of her mother's and grandmother's stories, there was much she did not know: 'Documenting their reparations became my way to make their respective pasts unfold' (p. 7). How did each experience the identity of a Holocaust survivor and what constituted mourning for them? Vera Slyomovics, for instance, was an early and active Holocaust educator in Canada. How did the environment of Montreal, with its high percentage of Holocaust survivors, and Vancouver shape the knowledge about the Holocaust produced by community educators such as Vera and scientist-survivors such as psychiatrist Robert Krell? How have the bureaucracies disbursing reparations functioned and changed? What kind of relationships have emerged between reparations bureaucracies and the recipients of reparations, and what relationships are spawned or deepened beyond that dyad by the circulation of reparation monies? Gizella directed hers in part towards the author's education, entwining the author in her reparations decision. Gizella gave it away to charities and Vera still does, divided into chunks of ritualized size. Can or do reparations end?

Chapter 6 traces a line of inquiry that stemmed from Slyomovics's study of the German reparations bureaucracy: how Algerian Jews interned in certain North African camps during World War II came to be eligible for reparations. They were defined as racial victims - yet other Algerians, Moroccans, Tunisians and Libyans, defined as colonial subjects of France or Italy for what seem to be the same 'racial' reasons and also detained in camps, are ineligible for reparations, as their treatment was due to colonialism, not Nazism. Slyomovics traces out a process of separating out Jews, a population that was in part precolonial, from other groups present at the time of colonial conquest, from the Crémieux Decree that made Jews native to Algeria into French citizens in 1870, through the abrogation of it by Vichy France, its reinstatement, to the reparations process and the episodes of 'repatriation' of Algerian Jews to a France they had never left, and of large-scale emigration of North African Jews to Israel.

Chapter 7 explores the topic of reparations for French and German colonialism more generally. Only in this chapter does it clearly emerge that Slyomovics has a definite opinion about reparations: they should be offered and one should accept them (p. 268). While she displays nothing but respect for her mother's decisions, still her book implicitly argues that in 1999 her mother made the 'right' choice. Drawing upon Simmel's Philosophy of Money, she argues that reparations create webs of meaning by putting money into circulation, which [End Page 342] in turn leads to the comparison and linkage of very different events (which is a good thing) and to participants in this circulation becoming oriented to the future. Slyomovics advocates reparations for colonial atrocities, claiming with John Torpey that they would be 'forward looking' rather than 'commemorative' (p. 240). Whether or not they are 'forward looking' - it seems to me to be no deficiency if they are not - there are compelling arguments for reparations for colonial wrongs. They need not rest only on the argument of Aimé Césaire and Frantz Fanon that Slyomovics puts forward here: that the crimes of the Holocaust were crimes of treating Jews as if 
they were colonial subjects. Slyomovics connects this discussion to some brief and insightful examinations of United States payments of 'blood money' to Iraqis, Pakistanis and Afghans whose relatives have been killed by servicemen or private contractors since 2001, and of Israeli payments to relatives of Palestinians killed by Israeli soldiers. Potential readers will, I hope, see that this is several thoughtful books in one. 